\title{
Causal Role of Xylella fastidiosa in Oleander Leaf Scorch Disease
}

\author{
A. H. Purcell, S. R. Saunders, M. Hendson, M. E. Grebus, and M. J. Henry
}

First, second, and third authors: Department of Environmental Science, Policy and Management, University of California, Berkeley 94720-3112; fourth author: Department of Plant Pathology, University of California, Riverside 92521; fifth author: University of California Cooperative Extension, 21150 Box Springs Rd., Moreno Valley 92557.

Accepted for publication 6 October 1998.

\begin{abstract}
Purcell, A. H., Saunders, S. R., Hendson, M., Grebus, M. E., and Henry, M. J. 1999. Causal role of Xylella fastidiosa in oleander leaf scorch disease. Phytopathology 89:53-58.

A lethal leaf scorch disease of oleander (Nerium oleander) appeared in southern California in 1993. A bacterium, Xylella fastidiosa, was detected by culturing, enzyme-linked immunoassay, and polymerase chain reaction in most symptomatic plants but not in symptomless plants or negative controls. Inoculating oleanders mechanically with X. fastidiosa cultures from diseased oleanders caused oleander leaf scorch (OLS) disease. The bacterium was reisolated from inoculated plants that became diseased. Three species of xylem sap-feeding leafhoppers transmitted the bacterium from oleander to oleander. The bacterium multiplied, moved system-
\end{abstract}

ABSTRACT

Oleander (Nerium oleander L.) is a particularly popular landscaping plant in California because it can be used for hedges and visual barriers and is easy and inexpensive to establish and maintain with minimal irrigation and pruning. Oleander leaf scorch (OLS) is a recently recognized disease (3) in southern California. OLS disease has caused the deaths of oleander plants in the Palm Springs area of the Coachella Valley in southern California since the late 1980s. In 1994 researchers began evaluating dying oleanders from Rancho Mirage, CA, in hopes of identifying the cause of increasing numbers of deaths in mature (up to 30 years old) oleanders in the area. Initial root and branch observations did not suggest or reveal any common pathogens. OLS was first reported in North Palm Springs and spread eastward to Indio, CA, in 1994.

Symptoms of OLS in the Palm Springs area were most prominent in hedges of oleander along golf courses and large estates. In initial investigations of diseased oleanders, commercial enzymelinked immunosorbent assay (ELISA) diagnostic tests (Agdia, Elkhart, IN) were positive for the bacterium Xylella fastidiosa (12). In 1995 similar symptoms were observed on oleanders growing in Tustin, Orange County, CA. The plants were a mixture of old and recently planted oleanders. Two private consultants submitted samples for ELISA testing, and the positive results encouraged us to attempt to confirm, by completing Koch's postulates, that $X$. fastidiosa was the cause of OLS.

$X$. fastidiosa is a xylem-limited bacterium that causes plant diseases characterized by leaf scorch symptoms in grape, almond, plum, elm, oak, and other plants and stunting in peach, alfalfa, and some weeds (14). Strains of $X$. fastidiosa vary significantly in host range. For example, strains that cause Pierce's disease (PD) of grapevine do not infect peach, and peach strains do not cause disease in

Corresponding author: A. H. Purcell

E-mail address: purcell@ nature.berkeley.edu

Publication no. P-1998-1116-02R

(C) 1999 The American Phytopathological Society ically, and caused wilting in Madagascar periwinkle (Catharanthus rosea) and leaf scorch in periwinkle (Vinca major) in a greenhouse after inoculation with needle puncture. No bacterium was reisolated from grapevine (Vitis vinifera), peach (Prunus persica), olive (Olea europaea), California blackberry (Rubus ursinus), or valley oak (Quercus lobata) mechanically inoculated with OLS strains of X. fastidiosa. A 500-bp sequence of the $16 \mathrm{~S}-23 \mathrm{~S}$ ribosomal intergenic region of oleander strains showed $99.2 \%$ identity with Pierce's disease strains, $98.4 \%$ identity with oak leaf scorch strains, and $98.6 \%$ identity with phony peach, plum leaf scald, and almond leaf scorch strains.

Additional keywords: Graphocephala, Homalodisca coagulata, Homalodisca lacerta, sharpshooter, vector transmission.

grapevines (6), but PD strains do cause disease in almond (11) and alfalfa (8). Xylem sap-feeding suctorial insects, such as sharpshooter leafhoppers (Homoptera: Cicadellidae), transmit the bacterium from plant to plant $(1,13,16)$.

We obtained our first in vitro isolates of $X$. fastidiosa from oleanders with marginal leaf scorch and decline in 1995. Some strains of $X$. fastidiosa infect numerous host species without causing symptoms $(2,7)$, and we were unable to positively confirm the presence of $X$. fastidiosa in all symptomatic oleanders. For these reasons, we attempted to (i) establish the consistency of the occurrence of $X$. fastidiosa in oleanders with leaf scorch syndrome; (ii) infect oleanders with $X$. fastidiosa from pure cultures isolated from symptomatic oleander plants; (iii) reproduce symptoms associated with the new disease; (iv) transmit $X$. fastidiosa from infected to uninfected oleanders with sharpshooter leafhoppers; (v) test the potential of other plants to serve as propagative hosts for oleander strains of X. fastidiosa; and (vi) compare the sequence of the $16 \mathrm{~S}-23 \mathrm{~S}$ rRNA spacer region of oleander strains of $X$. fastidiosa to strains of $X$. fastidiosa that cause other diseases in grape, peach, oak, plum, and almond. The rRNA genetic locus, rrn, in most prokaryotes includes the $16 \mathrm{~S}, 23 \mathrm{~S}$, and $5 \mathrm{~S}$ ribosomal RNA (rRNA) genes. The $16 \mathrm{~S}$ rRNA gene contains highly conserved sequences that have been used to analyze relationships among distant taxa and variable regions that allow differentiation of genera and species. The three genes are separated by noncoding spacer regions that exhibit considerable sequence and some length variation at the genus and species levels. Hence, the $16 \mathrm{~S}-23 \mathrm{~S}$ region frequently has been used to differentiate among different species of prokaryotes (20). We used the sequence of the spacer region to evaluate the taxonomic relationship of the bacterium isolated from oleander with leaf scorch to strains of $X$. fastidiosa that cause PD of grapevine, almond leaf scorch (ALS), plum leaf scald, oak leaf scorch, and phony peach disease.

\section{MATERIALS AND METHODS}

Vector and plant sources and insect transmission. All test or insect-rearing plants were propagated in greenhouses continuously 
ventilated with charcoal-filtered air to exclude airborne insects. Grapevine (Vitis vinifera L. 'Pinot noir'), Madagascar periwinkle (Catharanthus rosea (L.) G. Don), valley oak (Quercus lobata Née), and peach (Prunus persicae L. 'Lovell') were propagated from seeds. California blackberry (Rubus ursinus Cham. \& Schltdl.) was propagated from rooted cuttings from several greenhousesown seedlings. Periwinkle (Vinca major L.) was propagated from rooted cuttings from a plant collected in Ashland, OR, that tested negative during repeated attempts (described below) to culture $X$. fastidiosa. Olive plants (Olea europaea L.) were purchased commercially in containers. We purchased potted oleanders commercially in 1995 and, thereafter, grew them from seeds collected in Vacaville, CA. Potted oleanders from disease-free sources were used in experiments in Riverside, CA.

Three vector species, the blue-green sharpshooter (BGSS), Graphocephala atropunctata (Signoret); the glassy-winged sharpshooter, Homalodisca coagulata (Say); and the smoke tree sharpshooter, Homalodisca lacerta (Fowler), were used. Adult BGSS were collected from ornamental shrubs and trees in Berkeley, CA. Adult H. coagulata and $H$. lacerta were collected from ornamental shrubs in Tustin or from citrus groves of the University of California at Riverside. All insects used in transmission experiments were prescreened before they were used in experiments to ensure they were not infective for $X$. fastidiosa. For prescreening, groups of one to six insects were confined on oleander plants for two or more days. After more than 8 weeks, screened plants were tested for $X$. fastidiosa by culturing. Because none of the prescreened groups of sharpshooter leafhoppers transmitted $X$. fastidios $a$ to the prescreened plants, they were presumed to have been free of $X$.

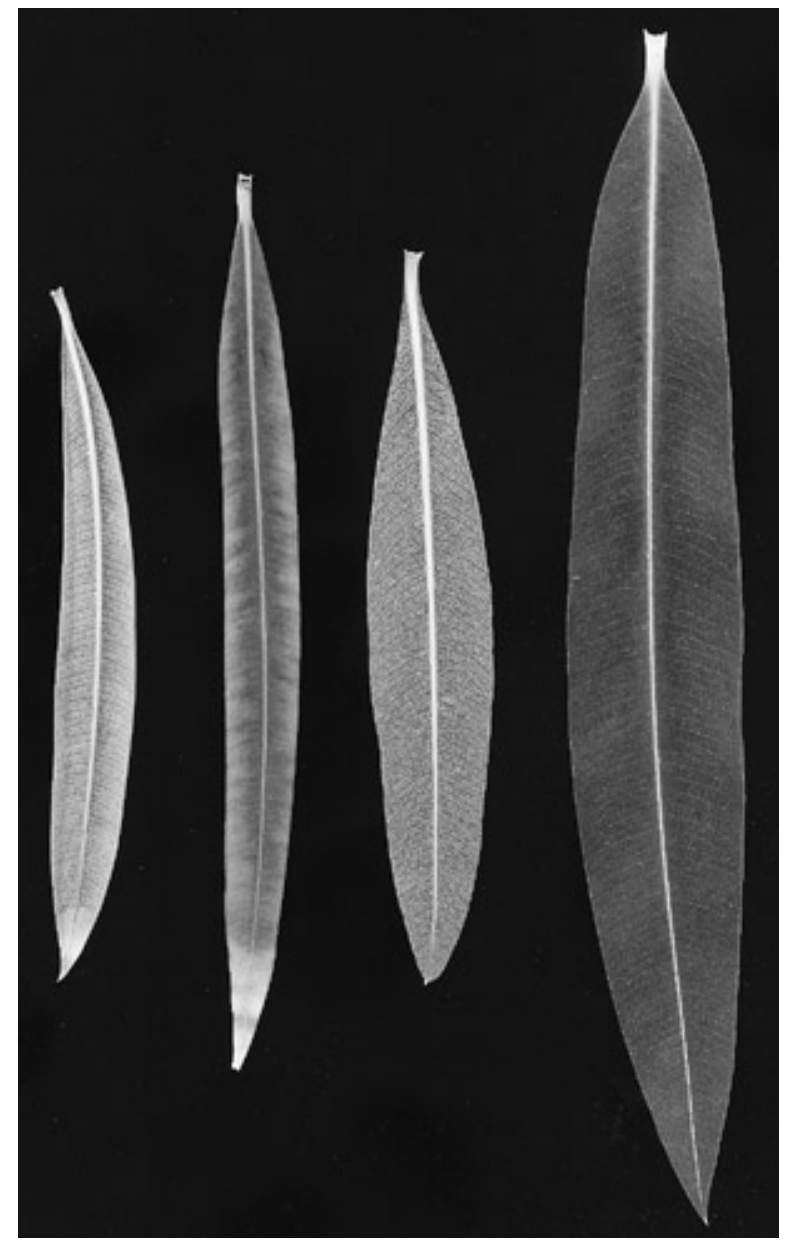

Fig. 1. Symptoms of leaf scorch disease in greenhouse-grown oleander plants inoculated with oleander strains of Xylella fastidiosa. Smaller leaves on the left are from inoculated, symptomatic plants; leaves on the right are from uninoculated controls. fastidiosa when used in the experiments. Prescreened sharpshooters (except as noted below) were caged for 1 to 4 days on oleanders confirmed by culturing as infected with $X$. fastidiosa. Sharpshooters were transferred with an aspirator, singly or in groups of three to six insects, onto test plants for 3 to 8 days. Negative controls were prescreened, and uninoculated plants were kept in the same greenhouse compartments.

Culturing and ELISA. The methods for culturing $X$. fastidios (sample preparation, surface-sterilization, PWG growth medium, and dilution-plating) were as previously described (5). Dilutionplating (undiluted and two 100-fold dilutions) of X. fastidiosa was used to estimate the number of viable bacterial cells (colony forming units per gram of plant tissue) in some experiments. The theoretical detection threshold for this method was calculated as $\approx 100$ cultivable cells per sample $(1,000 \mathrm{CFU} / \mathrm{g})(5)$. The characteristic appearance, growth rate, and growth pattern of colonies of $X$. fastidiosa on PWG medium (5) were regarded as positive identification, but to further ensure that the bacteria detected were correctly identified as $X$. fastidiosa, we tested arbitrarily selected samples, using polymerase chain reaction (PCR), as described below.

ELISA was performed according to the manufacturer's instructions (Agdia), with the following modifications. Approximately $3 \mathrm{~cm}$ of midrib was cut from a leaf, chopped, and placed in $1 \mathrm{ml}$ of phosphate buffered $0.85 \%$ saline (PBS) on ice before grinding. ELISA plates were incubated overnight at $4^{\circ} \mathrm{C}$ and rinsed four times with distilled water and four times with PBS. Plates were read after $15 \mathrm{~min}$ at $490 \mathrm{~nm}$ on an E-Max microplate reader (Molecular Devices Corp., Sunnyvale, CA).

Mechanical inoculation. Oleander leaves bled profusely from needle punctures, so we used a vacuum pump to facilitate uptake of suspended $X$. fastidiosa cells for mechanical inoculation of oleanders at Berkeley. We wrapped stretched Parafilm M (American Can Corp., Greenwich, CT) to form a Parafilm sleeve just below a freshly cut stem apex. We connected a rubber tube from the vacuum pump by pushing it onto the Parafilm sleeve, which provided an airtight seal. We pipetted a small drop of turbid suspension $(\approx \log 8$ cells $/ \mathrm{ml})$ of $X$. fastidiosa in PBS taken from culture plates onto a stem $\approx 5$ to $8 \mathrm{~cm}$ below the severed stem apex. With the vacuum pump running, we repeatedly probed the drop with a no. 2 insect pin until we observed uptake from the drop. Needle inoculations of PBS served as negative controls. We needle-inoculated grapevine, olive, periwinkle, and valley oak plants as described above but without vacuum, because vacuum was unnecessary for uptake in these species.

Three bacterial isolates (listed below) from oleander with OLS symptoms and one isolate from a PD-affected grapevine were used. In a trial at Riverside, oleanders were inoculated with a scalpel dipped in suspensions of $X$. fastidiosa cultured from oleanders. Each of 12 plants were wounded at five arbitrarily selected locations: a stem near the top of the plant and four leaves. Six plants similarly wounded by a scalpel dipped in buffer were negative controls. An additional 12 plants were injected with $50 \mathrm{ml}$ of suspended cells in a succulent stem, using a sterile hypodermic needle. Six buffer-injected oleanders were controls. A leaf from each inoculated plant was tested by culturing and ELISA for $X$. fastidiosa on seven dates at approximately monthly intervals.

DNA extraction from bacterial cells. Strains of $X$. fastidiosa were isolated in California from oleander from Palm Springs (Ann1), Cathedral City (PF1), and Tustin (T1c and TR1); from grapevine from Napa Valley (STL), Sonoma Valley (VinoF), and southern California (UCLA); and from almond (ALS1 and Dixon) from the northern San Joaquin Valley. Peach, plum, and oak strains (5S2, $2 \# 4$, and 88-9, respectively) were obtained from D. L. Hopkins, University of Florida, Leesburg. DNA was extracted using a modification of the cetyltrimethylammoniumbromide minipreparation method described by Wilson (19). Strain Ann1 was deposited with the American Type Culture Collection (Manassas, VA) as ATCC 700598 . 
DNA extraction from plant material. Petioles and leaf midribs $(\approx 4 \mathrm{~cm}$ long) and slices (cross-section, $\approx 1 \mathrm{~cm}$ total length) of stem tissue were removed from plant samples with sterile razor blades. DNA was extracted from plant tissue as described by Zhang et al. (21).

PCR. In PCR reactions for specific detection of $X$. fastidiosa strains, primers RST31 (5'-GCGTTAATTTTCGAAGTGATTCGATTGC-3') and RST33 (5'-CACCATTCGTATCCCGGTG-3') were used as described by Minsavage et al. (10).

Amplification of the 16S-23S rRNA intergenic spacer region was performed with primers G1 and L1, which are located in highly conserved regions within the $16 \mathrm{~S}$ and $23 \mathrm{~S}$ rRNA genes, respectively (9). PCR reactions contained $25 \mathrm{ng}$ of genomic DNA, 25 pmol G1, 25 pmol L1, $10 \mathrm{mM}$ Tris (pH 8.0), $50 \mathrm{mM} \mathrm{KCl}$, $2.5 \mathrm{mM} \mathrm{MgCl}_{2}, 200 \mathrm{mM}$ each of dATP, dCTP, dGTP, and dTTP, and $0.5 \mathrm{U}$ of AmpliTaq DNA polymerase (Perkin-Elmer, Foster City, CA). A DNA thermal cycler (Perkin-Elmer) was used: 1 cycle of $5 \mathrm{~min}$ at $94^{\circ} \mathrm{C} ; 35$ cycles of $94^{\circ} \mathrm{C}$ for $40 \mathrm{~s}, 55^{\circ} \mathrm{C}$ for $1 \mathrm{~min}$, and $72^{\circ} \mathrm{C}$ for $2 \mathrm{~min}$; and a final extension of $10 \mathrm{~min}$ at $72^{\circ} \mathrm{C}$.

Agarose gel electrophoresis of amplification products was performed in $1.4 \%$ agarose gels in Tris-acetate-EDTA buffer (15) at $3.5 \mathrm{~V} / \mathrm{cm}$. After staining in ethidium bromide, amplification products were visualized on a UV transilluminator, and photographed with a Polaroid (Cambridge, MA) land camera.

Sequencing of the 16S-23S rRNA spacer region. Amplified $16 \mathrm{~S}-23 \mathrm{~S}$ intergenic spacer regions synthesized with primers G1 and L1 (25-ml volume) were purified with Ultrafree tubes (Millipore Corp., Bedford, MA). Sequencing was performed with an ABI 377 automated sequencer as recommended by the manufacturer (Perkin-Elmer, Applied Biosystems).

\section{RESULTS}

Symptoms and occurrence of OLS in southern California. The first sign of leaf scorch in oleanders in the field or greenhouse usually was chlorotic mottling along the edges of leaves, changing over days and weeks to uniform chlorotic mottling of marginal leaf tissue that rapidly dried to a straw color along the leaf margin, especially at the leaf tip (Fig. 1). In the cool climate of coastal Orange County, OLS symptoms appeared most frequently during late summer after hot weather. Until then, symptoms consisted of generalized stunting of leaves and internodes and uneven yellowing of leaves. Symptoms spread progressively throughout the plant: first through a portion of a branch, then the entire branch, followed by additional branches until the entire plant was affected. Scorched tissues died and became straw colored.

Symptoms progressed most rapidly during early to mid-summer through early fall. Leaf scorching developed more rapidly in the hot desert climate of Palm Springs than in cooler coastal areas. Some plants defoliated as they declined, covering the ground surrounding the shrub with leaves. Typically, plants did not die until a year or more after the first signs of OLS. Foliar symptoms of OLS generally resembled those of drought stress or salt burn, except for initial chlorotic mottling or spotting of leaves in plants affected by OLS. Mottled chlorosis was subtle in some leaves but could be seen as long as there was live green tissue and was more easily observed indoors than outdoors in full sunlight. This pattern of chlorosis was readily apparent on stunted regrowth of stems after severe pruning of dead or declining branches.

OLS has continued to spread outward from two initially recognized infection centers in southern California. By early 1998, OLS had been detected as far south as San Diego and as far north as eastern Riverside and San Bernadino counties. During August 1998, we cultured $X$. fastidiosa from oleander plants from Galveston, TX, with leaf scorch symptoms.

Inoculation of oleander strains of $X$. fastidiosa in oleander and other plant species. All three oleander-derived strains of $X$. fastidiosa, inoculated in oleander seedlings or commercially obtained plants at Berkeley, caused OLS symptoms (Fig. 1). We cultured $X$. fastidiosa from all symptomatic, inoculated oleanders and never isolated $X$. fastidios $a$ from buffer-inoculated or uninoculated oleanders maintained simultaneously in the same greenhouse (Table 1).

The range of symptoms in greenhouse-maintained, inoculated oleanders was the same as that noted for field-grown plants. In the greenhouse at Berkeley, lateral marginal scalding appeared only in a few plants. We cultured $X$. fastidiosa from some oleanders as soon as 2 months after inoculation but from other plants only after several additional months (Table 2). The incubation period between inoculation and first appearance of symptoms varied from 5 to 13 months in the greenhouse at Berkeley. Some plants failed to develop tip or marginal scalding. Instead, the plants remained stunted, with generalized mild chlorosis similar to numerous declining oleanders observed in Orange County from which we isolated X. fastidiosa. In the greenhouse at Riverside, all plants, including negative controls, developed some degree of mild foliar chlorosis and tip burn during the 5 months after inoculation, but after 6 months or longer, severe stunting of new leaves and extensive leaf scorch occurred only in plants from which $X$. fastidiosa was cultured.

Both PD and oleander strains of $X$. fastidiosa systemically infected both species of periwinkle ( $V$. major and $C$. rosea) after mechanical inoculation at the same time. Under greenhouse conditions, an oleander strain caused leaf scorch symptoms in V. major,

TABLE 2. Results of isolation of Xylella fastidiosa on artificial medium and polymerase chain reaction (PCR) from leaf scorch-diseased oleander leaf samples ${ }^{a}$ (Berkeley, CA, 1995-1996)

\begin{tabular}{|c|c|c|c|}
\hline $\begin{array}{l}\text { California location } \\
\text { (type of area) }\end{array}$ & Date & Culture $^{b}$ & $\mathrm{PCR}^{\mathrm{b}}$ \\
\hline \multirow{2}{*}{$\begin{array}{l}\text { Palm Springs } \\
\quad \text { (landscape hedge) }\end{array}$} & & & \\
\hline & $\begin{array}{r}17 \text { Oct. } 1995 \\
3 \text { Feb. } 1996\end{array}$ & $\begin{array}{l}1 / 3^{c} \\
0 / 3\end{array}$ & $\begin{array}{l}\text { ND } \\
0 / 3\end{array}$ \\
\hline Cathedral City & 23 Feb. 1996 & $4 / 10$ & $6 / 8^{d}$ \\
\hline $\begin{array}{l}\text { Rancho Mirage } \\
\text { (residential hedge) }\end{array}$ & 3 Feb. 1996 & $0 / 3$ & $0 / 3$ \\
\hline $\begin{array}{l}\text { Tustin } \\
\text { (shopping center) }\end{array}$ & 3 Feb. 1996 & $5 / 6$ & $4 / 4^{\mathrm{d}}$ \\
\hline $\begin{array}{l}\text { Tustin Ranch } \\
\text { (residential hedge) }\end{array}$ & 3 Feb. 1996 & $3 / 3$ & $3 / 3$ \\
\hline
\end{tabular}

${ }^{a}$ Samples from the same plants were assayed simultaneously by PCR and culturing on each date listed.

${ }^{\mathrm{b}}$ Number of plants from which $X$. fastidiosa was positive for culturing or PCR/ number of plants assayed. $\mathrm{ND}=$ not done.

c Plants were in mail 2 to 3 days.

d Two fewer plants assayed by PCR on the same date.

TABLE 1. Recovery of Xylella fastidiosa from oleanders inoculated with strains of Xylella fastidiosa from leaf scorch-diseased oleanders

\begin{tabular}{|c|c|c|c|c|}
\hline Cultivar & Artificial media & Later attempts & Control plants ${ }^{\mathrm{a}}$ & Strain used (location) \\
\hline Petite pink & $1 / 3(43)^{b}$ & $2 / 2(350)$ & $0 / 3$ & PF1 (Cathedral City, CA) \\
\hline \multirow{2}{*}{ White flowered } & $0 / 3(30)$ & $3 / 3(100)$ & $0 / 3$ & Ann1 (Palm Desert, CA) \\
\hline & $2 / 3(50)$ & $1 / 1(350)$ & $0 / 2$ & TF1 (Tustin, CA) \\
\hline Odorum & $9 / 10$ & Not attempted & $0 / 10$ & Ann1 (Palm Desert, CA) \\
\hline
\end{tabular}

a Control plants of same species inoculated with buffer only.

${ }^{\mathrm{b}}$ Number of plants from which X. fastidiosa was cultured/number of inoculated plants tested. Number of days after inoculation is indicated in parentheses. 
whereas a PD strain (STL) caused milder scorch symptoms that appeared 2 to 3 months later than did symptoms caused by the oleander strain (Ann1). C. rosea plants developed wilt symptoms after 11 months in the greenhouse after needle-inoculation of branches with oleander strains. Other stems on the same plants wilted 2 to 4 months later. We detected $X$. fastidiosa in all six inoculated $V$. major plants after 3 months in a greenhouse and observed limited leaf drying and necrosis (scorch) of leaf margins after 7 to 8 months in two separate experiments. A PD strain (STL) inoculated in periwinkle caused noticeably milder leaf scorch than did an oleander strain (Ann1). Madagascar periwinkle inoculated with grapevine strains was slightly stunted, with fewer and smaller leaves and flowers.

We did not recover OLS strains of $X$. fastidiosa from 13 grapevines (two experiments, assessed by culturing 3 and 8 months after inoculation), 3 peach trees (assessed 68 and 340 days postinoculation), or 6 valley oaks (assessed 186 days postinoculation) after needle-inoculations, nor did we recover the bacterium from two buffer-inoculated peach tree controls. We could not inoculate peach strains of $X$. fastidiosa as positive controls for peach because of quarantine restrictions in California. We did not use PD strains in grapevine as positive controls in these experiments, but needleinoculation of grape is routinely successful in causing PD from grapevine-derived strains $(5,7)$. We failed to recover $X$. fastidiosa from three California blackberry plants (assessed 128 days postinoculation) inoculated with an OLS strain (Ann1), whereas we cultured $X$. fastidiosa from one or more (usually three) of three blackberry plants inoculated on the same date with one of two ALS strains (ALS1 or Dixon) or one of three PD strains (STL, VinoF, or UCLA), for a total of 12 of 15 plants that were positive for X. fastidiosa. We also inoculated California blackberry and periwinkle with an OLS strain (Ann1) and, after 100 days, cultured $X$. fastidiosa from five of the seven periwinkle but none of the seven inoculated blackberry plants. In tests with olive and grape as hosts, we did not culture $X$. fastidiosa from any of the six olive plants or nine grapevines inoculated with an OLS strain (Ann1), but we did culture $X$. fastidiosa from all six of the positive control oleanders inoculated with the OLS strain.

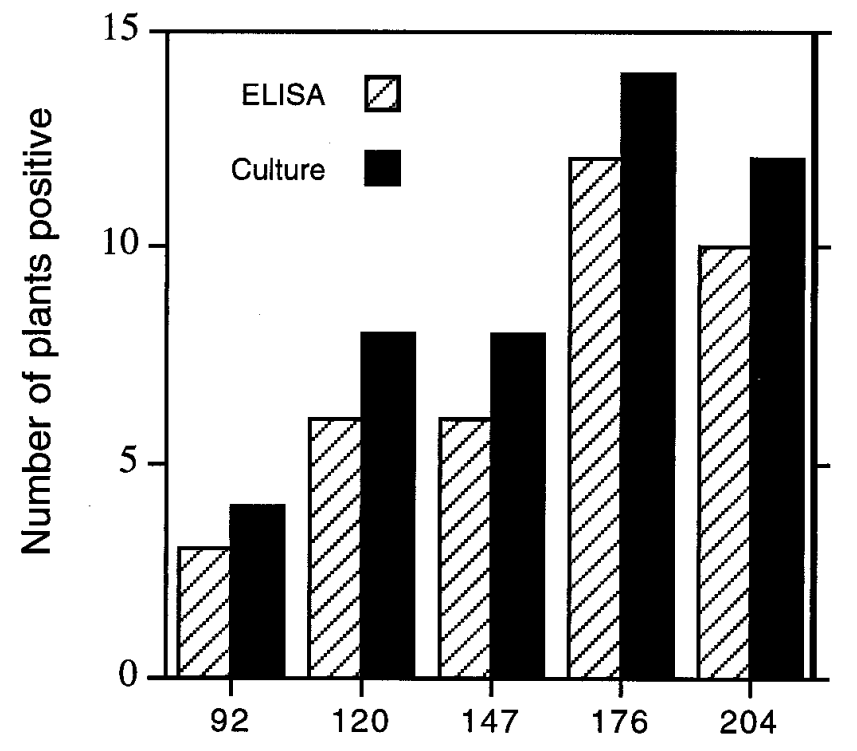

Days after inoculation

Fig. 2. Culturing and enzyme-linked immunosorbent assay (ELISA) results for oleanders infected with cultured Xylella fastidiosa at five approximately monthly intervals. Twenty-four plants were inoculated by scalpel-wounding or hypodermic needle; fifteen plants tested positive by culturing on at least one sample date. All inoculated plants tested negative by both methods 33 and 60 days postinoculation.
Culturing, ELISA, and PCR of oleander tissues. We cultured $X$. fastidiosa from most, but not all, oleanders with leaf scorch symptoms in field locations in southern California (Table 2). PCR performed on leaf samples generally confirmed results from cultures from the same samples (Table 2). Amplification products of identical size $(\approx 0.7 \mathrm{~kb})$ were synthesized by PCR with primers RST31 and RST33 and genomic DNA from strains of $X$. fastidiosa causing PD, ALS, plum leaf scald, citrus variegated chlorosis, oak leaf scorch, and sycamore leaf scorch.

The highest titers of $X$. fastidiosa estimated by dilution-plating from oleander were $\approx 10^{8} \mathrm{CFU} / \mathrm{g}$ of plant tissue (petioles), measured 1 year after inoculation. Some infected oleanders kept under greenhouse conditions yielded only $\approx 10^{6} \mathrm{CFU} / \mathrm{g}$, and the bacterium was not always cultured from the same diseased oleanders on subsequent dates or from all sampled leaves or stems from the same diseased plants more than 14 months after inoculation, showing that cultivable cells of the bacterium were irregularly distributed in plants with OLS symptoms. Populations of X. fastidiosa apparently rise and fall over time in greenhouse-grown plants.

Neither culturing nor ELISA of sampled leaf midribs from oleanders that had been mechanically inoculated at Riverside on 1 October 1996, by scalpel or hypodermic injection, gave positive results 33 and 60 days postinoculation. After 91 days, four plants (three needle-inoculated and one scalpel-inoculated) were positive by culturing, and three of the same plants were positive by ELISA. We initially used an arbitrary threshold value of more than twice the absorbency reading of the negative control sample as a positive reading, but the lowest ratio realized in any assay was 3.2, which occurred on the 91 days postinoculation sampling date. Over the next 4 months, the same 6 of 12 plants inoculated by scalpel

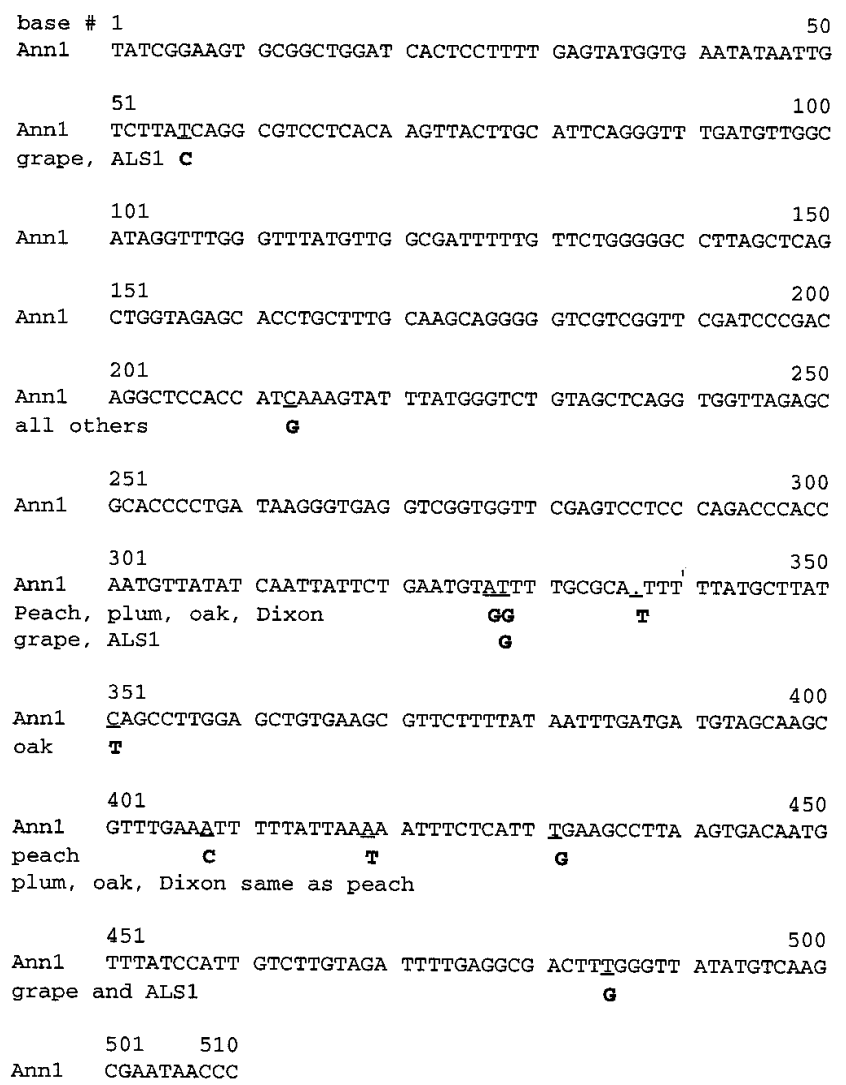

Fig. 3. Base sequences of DNAs from the $16 \mathrm{~S}-23 \mathrm{~S}$ intergenic regions of $X y$ lella fastidiosa strains from six host plant species. The top line shows the complete sequence for oleander reference strain Ann1 (ATCC 700598) and three other strains from oleander (PF1, TR1, and T1c). Deviations from Ann1 are shown in bold below underlined bases of Ann1 for strains from grapevine (STL, VinoF, and UCLA), peach (5S2), almond (ALS1 and Dixon), plum (2\#4), and oak (88-9). 
tested positive in both ELISA and culturing, and the same 9 of 12 plants inoculated by needle tested positive in both methods.

Culturing resulted in slightly higher numbers of positive plants than ELISA for each of the five sampling dates that gave positive results (Fig. 2). No plant tested positive on all sampling dates. Two of the scalpel-inoculated plants tested positive on only one date of the last five monthly sampling dates; 10 of the remaining 13 plant samples tested positive on three or four of the last five sampling dates. Considering only those plants from which $X$. fastidiosa was cultured at least once, 37 of 75 samples taken after 90 days postinoculation were positive in ELISA, and X. fastidiosa was cultured from 46 of 69 uncontaminated samples. $X$. fastidiosa was cultured from all plants that were positive in ELISA, except for six culture attempts spoiled by contaminating bacteria or fungi.

Comparison of the sequence of the 16S-23S intergenic spacer region. A PCR product of $\approx 500 \mathrm{bp}$ was synthesized for all strains tested with primers G1 and L1. Figure 3 shows the sequences of the 16S-23S rRNA spacer region of strains causing PD, ALS, phony peach, plum leaf scald, and OLS. The level of identity between oleander and grapevine, almond (ALS1, grape-like), maple (grapelike), almond (Dixon), plum, peach, and oak strains was 99.2, 99.2, 99.2, 98.6, 98.6, 98.6, and 98.4\%, respectively. GenBank accession numbers for Ann1, PF1, T1c, TR1, STL, VinoF, ALS1, Dixon, 5S2, 2\#4, and 88-9 are AFO73215, AFO73216, AFO73217, AFO73218, AFO73228, AFO73233, AFO73231, AFO73240, AFO73251, AFO73206, AFO73209, and AFO73210, respectively.

Vector transmission. All three sharpshooter species (subfamily Cicadellinae) transmitted $X$. fastidiosa to oleander after feeding on oleanders from which we previously had cultured the bacterium (Table 3). The same BGSS that transmitted to oleander did not transmit X. fastidiosa to grape. A total of 16 BGSS survived on grape for 2 days in the tests. Typically, more than $90 \%$ of the sharpshooters survived after 24 to $48 \mathrm{~h}$ on $X$. fastidiosa-infected oleanders.

\section{DISCUSSION}

The bacterium we isolated from oleanders with leaf scorch symptoms that caused symptoms after inoculation in other oleanders should be considered a newly discovered strain of $X$. fastidiosa (18). Supporting evidence for identification as $X$. fastidiosa include serological (ELISA) reactivity of the bacterium with antiserum raised against another strain of $X$. fastidiosa, close similarities of the 16S-23S intergenic sequence to other strains, and PCR synthesis of a similar, if not identical, DNA fragment with primers (10) designed and shown by testing to be diagnostic for $X$. fastidiosa.

The fulfillment of Koch's postulates established that $X$. fastidiosa caused OLS disease. X. fastidiosa was consistently, but not always, detected in diseased plants, as indicated by our PCR and

TABLE 3. Transmission of Xylella fastidiosa from oleander to oleander by sharpshooters

\begin{tabular}{lccc}
\hline Sharpshooter species & $\begin{array}{c}\text { No. of } \\
\text { insects/plant } \\
\text { (range) }\end{array}$ & $\begin{array}{c}\text { No. of } \\
\text { plants }\end{array}$ & $\begin{array}{c}\text { No. of plants } \\
\text { positive for } \\
\text { X. fastidios } a^{\text {a }}\end{array}$ \\
\hline Graphocephala atropunctata & $5-6$ & 4 & 4 \\
Homalodisca coagulata & 1 & 5 & 0 \\
Negative controls & $2-3$ & 3 & 3 \\
Homalodisca lacerta & $0^{\mathrm{b}}$ & 4 & 0 \\
Negative controls & $3-4$ & 8 & 0 \\
Total no. of inoculated plants & 1 & 8 & 2 \\
Total no. of negative controls & 0 & 3 & 0 \\
\hline
\end{tabular}

${ }^{a}$ Plants assayed by culturing on artificial medium (5).

${ }^{b}$ Field-collected insects were prescreened for infectivity on pretest plants that served as negative controls. culture results. The same field plants that were negative by PCR also were negative by culturing. Inoculation experiments at Riverside followed by both ELISA and culturing also suggested that live bacteria were not present in all symptomatic tissues or that bacteria had died if previously present. Strains from grapevines with PD did not cause OLS symptoms after either mechanical or vector inoculation, and we could not detect infection after inoculating oleander plants with PD strains, using mechanical or vector transmission. Because of the small number of peach plants we inoculated with the oleander strain, we cannot reject the possibility that oleander strains of $X$. fastidiosa might infect peach at a rate that would be detected when using more plants or that $X$. fastidiosa might establish transient, nonsystemic infections in peach. In light of the ability of some strains of $X$. fastidiosa to cause disease in more than one plant species (14), it is possible that this newly recognized strain will cause diseases in additional species of plants. Disease symptoms produced in the greenhouse by oleander strains of $X$. fastidiosa in periwinkle (C. rosea and V. major) have not yet been observed in the field.

Transmission of $X$. fastidiosa from oleander to oleander by two species of sharpshooter leafhoppers and development of leaf scorch symptoms in vector-inoculated plants further support our conclusion that $X$. fastidiosa causes OLS. Vector transmission would explain the natural spread of OLS observed so far. Our tests were not extensive enough to provide useful estimates of the efficiency of vector transmission.

The BGSS is widely distributed in California and abundant in many urban landscapes in coastal California (4). The smoke tree sharpshooter has become abundant on woody ornamentals in residential landscapes in numerous locations in southern California and also is common on citrus in Riverside County, for example, in both the Palm Springs and Riverside areas, and in southern coastal California (M. Blua, personal communication). The glassy winged sharpshooter (1) was first detected in California in 1990 (17) and has become extremely abundant on citrus and avocado in Orange County, without causing apparent symptoms of plant distress (N. Nissan, personal communication), and in eastern Riverside county (M. Blua, personal communication). High populations of $\mathrm{H}$. coagulata have been observed in Ventura County on citrus, sumac, crepe myrtle, and other ornamentals (P. Phillips, personal communication). Our collections of $H$. coagulata indicate that it feeds and reproduces on a wide range of woody ornamentals in southern California.

\section{ACKNOWLEDGMENTS}

Research was supported in part by the University of California Division of Agriculture and Natural Resources, Competitive Project 113 and in part by the American Vineyard Foundation. We thank M. Blua, University of California, Riverside, for assistance in collecting Homalodisca species. R. Geitner, Spring Mountain Vineyards, St. Helena, CA, provided olive plants. H. and W. Feil assisted in some experiments. D. Hopkins, University of Florida, Leesburg, provided strains of X. fastidiosa used for sequence comparisons.

\section{LITERATURE CITED}

1. Adlerz, W. C., and Hopkins, D. L. 1979. Natural infectivity of two sharpshooter vectors of Pierce's disease of grape in Florida. J. Econ. Entomol. 72:916-919.

2. Freitag, J. H. 1951. Host range of Pierce's disease virus of grapes as determined by insect transmission. Phytopathology 41:920-934.

3. Grebus, M. E., Henry, J. M., Hartin, J. E., and Wilen, C. A. 1996. Bacterial leaf scorch of oleander: A new disease in southern California. (Abstr.) Phytopathology 86 (Suppl.):S110.

4. Hewitt, W. B., Frazier, N. W., and Freitag, J. H. 1949. Pierce's disease investigations. Hilgardia 19:207-264.

5. Hill, B. L., and Purcell, A. H. 1995. Multiplication and movement of $X y-$ lella fastidiosa within grapevine and four other plants. Phytopathology 85:1368-1372.

6. Hopkins, D. L. 1989. Xylella fastidiosa: A xylem-limited bacterial path- 
ogen of plants. Annu. Rev. Phytopathol. 27:271-290.

7. Hopkins, D. L., and Adlerz, W. C. 1988. Natural hosts of Xylella fastidiosa in Florida. Plant Dis. 72:429-431.

8. Houston, B. R., Esau, K., and Hewitt, W. B. 1947. The mode of vector feeding and the tissues involved in the transmission of Pierce's disease virus in grape and alfalfa. Phytopathology 37:247-253.

9. Jensen, M. A., Webster, J. A., and Straus, N. 1993. Rapid identification of bacteria on the basis of polymerase chain reaction-amplified ribosomal DNA spacer polymorphisms. Appl. Environ. Microbiol. 59:945-952.

10. Minsavage, G. V., Thompson, C. M., Hopkins, D. L., Leite, R. M. V. B. C., and Stall, R. E. 1994. Development of a polymerase chain reaction protocol for detection of Xylella fastidiosa in plant tissue. Phytopathology 84:456-461.

11. Mircetich, S. M., Lowe, S. K., Moller, W. J., and Nyland, G. 1976. Etiology of almond leaf scorch disease and transmission of the causal agent. Phytopathology 66:17-24.

12. Opgenorth, D. 1995. Oleander leaf scorch associated with Xylella fastidiosa. Calif. Plant Pest Dis. Rep. 14:60-61.

13. Purcell, A. H. 1989. Homopteran transmission of xylem-inhabiting bacteria. Pages 243-266 in: Advances in Disease Vector Research, vol. 6. K. F. Harris, ed. Springer-Verlag, New York.

14. Purcell, A. H., and Hopkins, D. L. 1996. Fastidious xylem-limited bac- terial plant pathogens. Annu. Rev. Phytopathol. 34:131-151.

15. Sambrook, J., Fritsch, E. F., and Maniatis, T. 1989. Molecular Cloning: A Laboratory Manual. 2nd ed. Cold Spring Harbor Laboratory Press, Cold Spring Harbor, NY.

16. Severin, H. H. P. 1949. Transmission of the virus of Pierce's disease by leafhoppers. Hilgardia 19:190-202.

17. Sorensen, J. T., and Gill, R. J. 1994. A range extension of Homalodisca coagulata (Say) (Hemiptera: Clypeorrhyncha: Cicadellidae) to southern California. Pan-Pac. Entomol. 72:160-162.

18. Wells, J. M., Raju, B. C., Hung, H.-Y., Weisberg, W. G., Mandelco-Paul, L., and Brenner, D. J. 1987. Xylella fastidiosa new-genus new-species Gramnegative xylem-limited fastidious plant bacteria related to Xanthomonasspp. Int. J. Syst. Bacteriol. 37:136-143.

19. Wilson, K. 1987. Preparation of genomic DNA from bacteria, Pages 241245 in: Current Protocols in Molecular Biology. F. M. Ausubel, R. Brent, R. E. Kingston, D. D. Moore, J. G. Seidman, J. A. Smith, and K. Struhl, eds. Wiley Interscience, New York.

20. Woese, C. 1987. Bacterial evolution. Microbiol. Rev. 51:221-271.

21. Zhang, Y. P., Uyemoto, J. K., and Kirkpatrick, B. C. 1995. A rapid, small scale procedure for extracting virus, viroid, MLO and bacterial nucleic acids from plants for analysis by PCR. (Abstr.) Phytopathology $85: 1205$. 